\title{
THE PREFERRED MODEL OF ENGLISH FOR PERSONAL, NATIONAL, AND GLOBAL COMMUNICATION IN ELF CONTEXT: A COMPARATIVE STUDY BETWEEN FILIPINOS AND INDIANS
}

\author{
Olusiji Lasekan \\ Universidad de La Frontera, Temuco, Chile \\ sijilasekan@gmail.com
}

First received: 3I December 2017

Final proof received: 31 January 2018

\begin{abstract}
An experimental investigation was conducted to compare preferred models of English for personal, national, and global communication in ELF context between Filipinos and Indians. Drawing upon the data gathered through questionnaire and accent recognition survey from over 200 undergraduate students in these two nations, it was revealed that both nationals prefer British English for personal communication. But for national communication, Indians prefer their own standardized variety of English, i.e. Indian English, while the majority of Filipinos chose American English. British English and American English are considered to be the most ideal English varieties to express global identity by Indians and Filipinos, respectively. Finally, the degree of familiarity with the native English varieties which was higher among Filipinos than Indians is inversely proportional to level of awareness of their standard local English variety. Implications of the results and future research directions were also presented.
\end{abstract}

Keywords: personal; national; global communication; Indians; Filipinos

The concept of linguistic behavior and idealized norms propounded by Kachru (2005) has been used to investigate English variety preferences. The need for mutual intelligibility, especially in second language (L2) learning classroom, has heightened scholars' interest in this area of research in recent years.

Based on Kachru's classification of World Englishes into inner, outer, and expanding circles (Kachru, 1985), attitudes towards varieties of English among individuals in these three circles have been studied. For instance, there is a plethora of studies on perception of English varieties spoken among native English speakers within the inner circle and their attitude towards other varieties of English spoken in the outer and expanding circles, and vice versa (Tan \& Castelli, 2013; Tsui \& Bunton, 2000). The overall findings show that both outer and expanding circles prefer to speak and learn models of English used in the inner circle at the expense of their own standard local variety, while the inner circle members perceived varieties of English in the outer circle to be less inferior.

While the demand for British English (BrE) by speakers of English in Commonwealth countries is attributed to colonial history, geographical proximity to native English speaking countries has been used to explain the preference of Latin Americans for American English (AmE) (Lintunen, 2002). However, not much work on World Englishes research has been conducted between countries in the outer circle, such as the Philippines and India, which were once colonized by different colonizers such as the USA and Britain, respectively. This is critical in establishing the role of colonial history in the choice of English accent preference among English speakers within the outer circle. In addition, focusing on those two factors is not sufficient to justify individual difference choices (Jenkins, 2003). According to Kirkpatrick (2007), social and cultural factors influenced by prejudice and solidarity also need to be considered.

It is also important to point out that the discourse of aspired varieties of English being investigated over the years has centered on personal communication. There is yet to be a study on preferred models of English for groups of people who would like to present themselves as national and global citizens in ELF communication. This is significant considering that English variety can be used as a tool to construct a myriad of identities resulted from identification with personal, national, and global culture. According to Pennycook (2006), it is not that people use language varieties because of who they are, but rather people perform who they are by using different language varieties.

Therefore, the aim of this paper is to compare between Filipinos and Indians the preferred models of English for personal, national, and international communication. Additionally, in order to validate their preferences at these three levels of communication, the degree at which both groups are able to recognize $\mathrm{BrE}, \mathrm{AmE}$, and their respective local varieties will be investigated.

\section{History of English in India}

The permission to trade with India was given by Queen Elizabeth I to some English merchants on 
$31^{\text {st }}$ of December, 1660. This is commonly used to mark the coming of English into India (Ferguson, 1996). He stated that the permission provided an opportunity for missionaries to spread Christianity and do social works. But according to Kachru (as cited in McArthur, 2003) their work was restricted till the beginning of the $19^{\text {th }}$ century when the British House of Commons made a resolution to promote useful knowledge, religion, and moral improvement among native inhabitants of India. This called for the passing of Macaulay Minute of 1835 whose objective is to create a social class of Indians who can be the interpreters between Indians and the British. According to the author, this is the Minute that institutionalized English in India through the establishment of English-medium Universities in different parts of the country. The author added that the debate on what should be the official language of the country emanated in Postcolonial India. While Anglicists favored the promotion of English, the Orientalists opined that regional language should be promoted, especially in both primary and secondary education. The winning of the debate by the Anglicists led to the designation of English as an associated official language in 1967. That is, the language should be used along with the Hindi for all official purposes of the Union parliament and for communication between the State and the Union (Ferguson, 1996).

Even though several factors such as cultural, social, and political factors determine the position of English in different domains in India, the position of English among Hindi and other regional languages remains elusive (Kachru, 1983). The first question raised by the scholar is the position of English at every level of education. The second deals with the roles of Hindi and English, whereas the third question is concerned with the model of English that should be taught in schools and colleges. Considering that the use of this language has dominated every domain of the country (Hohenthal, 2003), it is therefore also important to question where the language is first learnt by the Indians.

\section{Indian English}

The definite conclusion on what constitutes Indian English (IE) as a variety of English is yet to be established. As a result of this, several authors have adopted different theoretical terms. Kachru (1985) described it as a transference variety. He stated that the uniqueness of IE is based on the context of situation. He further explained it as a situation where the same linguistic form performs different speech functions. In his observation, there are four types of Transfer. Transfer of context (caste system of India), Transfer of formal items, Transfer of speech functions (mode of address), and Transfer of meaning from L1 to L2.

\section{History of English in the Philippines}

For more than 300 years, the Philippines was colonized by Spain. For the fear of revolting against their colonizer, the majority of Filipinos were not allowed to have formal education. This in turn prevents them from learning Spanish language. The liberation of the Philippines from the Spaniards by the Americans in 1898 after a mock battle of Manila bay led to the mass education of Filipinos in English. The justification of the then US president was based on the need to civilize and unify the country for the purpose of guiding the country through the path of rapid development (Constantino, 1975). Over 1,000 American English teachers were recruited after the liberation to teach primary and high schools (Thompson, 2003). Even after the Philippines' independence from American occupation in 1945, Filipino schools continued to adopt English as the medium of instruction. That explains why English is adopted as a means of communication in various public domains. According to Vizconde (2006), Filipinos do not learn English as a foreign language because while some consider it as L1, it is regarded and adopted as L2 by other groups of people. The author states that for most middle and upper class Filipinos' children, English language learning begins at home.

\section{Philippine English}

Several views on Philippine English (PE) have been expressed. Popular perception portrays it as a broken English of showbiz and political personalities (Malicsi, 2010). PE was first defined by Liamzon (1969), who referred to it as the type of English spoken by educated Filipinos and that which is acceptable among educated Filipino circles. In other words, it can be described as the English output of educated Filipino professionals.

There are several issues associated with PE. Some scholars consider PE as inferior English to standard AmE (Gonzalez, 1983). The author raises a question about standardizing errors made in English. On the other hand, studies such as that by Bautista (2000) affirm the legitimacy of a variety of English which does not fall short of the standard AmE. Another dimension of Philippine English is the three different circles that exist within PE (Pefianco Martin, 2014). The author categorized the three circles within this outer circle into inner circle (educated elite who have embraced either Filipino/American English), outer circle which consists of individuals who may be aware of PE as a distinct and legitimate variety but are powerless to support it, and expanding circle of users of English for whom the language of whatever variety remains a requisite for upward mobility and largely inaccessible. Thus, this study will explore empirical evidence to support this categorization, both in India and the Philippines.

Attitude towards Varieties of English

Attitude as a theoretical concept has been defined 
majorly from cognitive stand point; it is an object of thought on dimension of judgment (McGuire, 1986). In other words, individuals' view of a particular language causes them to give a special position to the language among other languages. Therefore, the implication of investigating attitude towards a language has been helpful in providing valuable information on building better understanding of any language in question, thereby reducing detrimental effects on others. In the case of attitude towards varieties of English, a plethora of studies have been conducted (Tan \& Castelli, 2013; Castro \& Roh, 2013; Chan, 2015). The summary of these studies indicates that varieties of English within the inner circle are highly preferred by the Non-Native Speakers (NNS) of English who regard their own nativised variety as a lower standard variety. However, in spite of the extant of studies in this field, there are still findings which indicate how Native English Speakers (NES) show highly positive attitude towards NNS varieties of English (Jaber \& Hussein, 2011). Moreover, the preference of AmE by the Koreans has failed to explain the sole effect of colonial history and proximity to English speaking countries in choosing a certain model of English variety. Furthermore, few NNSs accord prestige to their own local variety of English at the expense of native English varieties. All these contradictory findings can be explained through the influence of societal perceptions which include cultural stereotypes. According to Bonvillain (2003), people tend to ascribe certain characteristics to speakers of a particular language or accent based on their stereotypes and beliefs about members of that community. Attitudinal variable factors such as solidarity are influenced by geographical or cultural characteristics closest to one's own language, while competence and prestige as attitudinal factors are associated to target language speakers' reputation for hard-work and good education and the amount of riches and technology in their country. In sum, language attitude research has demonstrated that the most powerful accents in a community receive high marks in status and competence, while less known languages and minority accents receive higher ratings in solidarity (Nesdale \& Rooney, 1996).

Personal, national, and global identity in ELF communication

It has been argued that English as an international lingua franca is not exclusively tied to its personal, national and cultural base (Jenkins, 2003). Dörnyei (2005), for example, associates the use of English among L2 learners with the expression of "a nonparochial, cosmopolitan, globalised citizen identity" (p. 97). That is, while many L2 speakers express a desire to preserve elements of their L1 accent in order to project their national/cultural identity in English, many express a desire for a global identity which gives them "a sense of belonging to a worldwide culture" (Arnett, 2002, p. 777), and aspires towards imagined identities as sophisticated English-speaking citizens of the world (Lamb, 2004). Since its usage cuts across speakers of different first languages, then ELF opposes the traditional monolithic standard of English "native speakers" (NSs) and stresses the equality of English users with different L1 backgrounds. Therefore, with respect to construction of identities in English as a Lingua Franca (ELF) communication context, it can be argued that the aspired variety of English can be expressed on the basis of personal, national, and global identities. This is important considering the dichotomy between the spoken standard and the aspired variety which is yet to be understood with respect to the construction of myriads of identities by English speakers for ELF communication. While the aspired variety of English for personal communication has been at the center of investigation over the years, the aspired variety for national and global communication is yet to be investigated.

The choice of English variety to express personal identity in ELF communication is highly influenced by the function of the language itself. As a result of this, English variety serves as a means of communication with the aim of expressing ones' unique identity in terms of who they are. In addition, it is used to express and identify and showcase one's culture. For instance, nativised variety of English is usually considered to be the best variety to signify one's cultural identity, which is very important to every speaker. Moreover, a successful ELF communication is based on the satisfactory degree of mutual intelligibility while retaining a comfortable measure of personal identity (Seidlhofer, 2006). Therefore, the aspired variety of English does not have to gravitate towards the variety of English spoken within the inner circle. Thus, self-identity is fluid, which is subject to interaction between people in different contexts. According to Kirkpatrick (2007), the link between function and variety can be called identitycontinuum. In other words, an individual might wish to use BrE/AmE in a formal gathering for the purpose of impressing the audience.

In the development of nativised variety of English for expressing national identity in ELF communication, Kachru (1992) describes the three phases of development of local varieties. The first phase involves non recognition of local variety whereby local variety is prejudiced against, and it is popularly believed that imported native speaker variety is superior and should be the model for language learning in school. The second phase emerges when the local and imported variety existed side by side. Even though the local variety is being used in a wide range of domains, it is still considered inferior to the imported variety. The last phase described occurs when the local variety is 
recognized as the norm and socially accepted. At this stage, local variety is taken as the preferred model for teaching in school, and speakers of imported varieties are seen as outsiders. Thus, this developmental cycle can be used to determine the status and acceptability of a local variety in a country by quantifying the number of people that prefer a certain variety of English for national communication. Several studies conducted in different contexts have adopted this cycle to investigate stages of national identity in ELF communication. In China, a two-year longitudinal study reveals that Chinese English develops from admiration of English-speaking cultures, antagonism towards alien things, and conciliation between the national and global (Gu, 2010).

The preferred model of English for national communication has been a battle between local variety users and language policy makers (Labov, 1966). While the latter are against the standard local variety because they assume it promotes economic pragmatism and serves as sustenance of elite statusquo, the former who occupy the bulk of the society support the learning and usage of a standard local variety because it reflects national identity and communal membership. This is the case in Singapore where there are two groups known as pro-Singlish and anti-Singlish (Chye, 2000). The author describes the anti-Singlish group as the group of language policy makers who believes that Singaporean English is the corruption of standard native English and advocates the abolishment of such variety in their society. The justification is on the assumption that standard native English will strengthen social rapport between the indigenous and foreign investors who are majorly British and Americans living in Singapore. On the other hand, pro-Singlish groups claim their own local variety is important in expressing their culture, value, and emotion. According to Smith (1978), most people around the world are not interested in sounding like the native English speakers or identifying with their culture, but several ministries of education insist on a native model of English for teaching while sometimes forbid the use of local variety as a model. As it is stated by Görlach (1998), the government's intention is to force their country to be part of the global village, thereby leaving the general populace in the position of national choice or need.

Past findings reported several main commonalities on how L2 learners understood and characterized their desired global identities in ELF contexts. Overall, it was found that the learners' perceptions of their global identities, or identities as global speakers of English, involve displaying positive orientations to both linguistic and cultural diversity in the global use of English (Sung, 2016). The author states that the interlocutors claim competences to engage in constant negotiations between different linguistic, cultural conventions and practices so that effective communication can be achieved in different ELF settings.

English has become a global language due to British imperialism which is responsible for the spread of the language in major parts of the world. This is coupled with the economic and political influence of the USA in the $21^{\text {st }}$ century (Crystal, 1999). All these made Received Pronunciation (RP) and General American (GA) the most popular English model for communication at international level. Certain factors which influence the choice of English model between the two native English varieties have been anchored on geo-cultural situations. The argument is that people tend to choose a certain accent of an English speaking country as a standard for pronunciation because of the proximity of such native English speaking countries. For instance, GA is the most preferred model of English in Latin America, while RP is most preferred among European countries (Gimson, 1981). Regarding the effect of colonial history, Commonwealth citizens tend to show solidarity to their former colonizer by adopting their accent for teaching and communication. Another positive attitudinal disposition towards British English is due to its politeness, correctness and charming of its sound (Alftberg, 2009). On the other hand, AmE is associated with incorrectness, but it is described to be more relaxed and flexible (Söderlund \& Modiano, 2002)

English variety awareness and accent identification This is a prerequisite to the measurement of attitudinal disposition towards a particular variety of English. It is important to determine the extent at which people are aware and familiar with their own variety of English and others. This measurement is carried out both by matched guise technique (MGT) and folk linguistics. While the former involves evaluating varieties of speech samples for certain attributes, the latter, which is a sociolinguistic approach, examines people's beliefs about a particular English variety (Jenkins, 2003).

Numerous studies have investigated the degree of awareness and identification of different English accents. In a survey conducted in Indonesian context, 164 students were asked to identify RP, GA, NZ and AE (Mardijono, 2005). The overall findings showed that GA was the most correctly identified accent followed by RP. The author stated that the level of awareness of these English varieties is highly influenced by the degree of exposure to the target accent which usually occurs through either contact with the native speakers of English or indirect contact through watching un-dubbed English movies and films. However, the only gap in the body of literature in this regard is the relationship between individuals' degree of awareness of local variety of English and the ability to identify native English accent. 


\section{METHOD}

\section{Research site and participants}

The choice of Central University of Karnataka as a research site was based on the need to carry out a Pan Indian study whereby responses were taken from 152 final year Indian students who come from different parts of the country. On the other hand, the Philippines consists of 18 administrative regions; therefore, in order to conduct similar all-inclusive research study, convenience sample data of 139 subjects were taken from $5^{\text {th }}$ semesters students in Philippine Women's University in the city of Manila and Southern Baptist College in North Cotabato. Participants in both countries were majoring in various fields of study, namely Business Administration, English, Education, Nursing, and Engineering. Specifically, the age range of the participants was between 21 and 26 years old. Each participant was selected on a voluntary basis, which means, he/she could voluntarily decide whether or not to take part as a research participant and to withdraw from the study at any time. Every participant was fully informed about the research goals, data collection procedures, as well as their privacy protection. All of them gave the researchers their consent to participate in the study before data collection took place. The number of participants from each nation was different because of limitations on accessibility and availability.

\section{Data Collection}

The research for the main part utilized quantitative methods, but wherever qualitative methods were being used, they followed the same logic as the quantitative methods. To some extent, the study replicated the methods used by previous studies in this area and allowed for some points of comparison.

\section{Survey}

A survey was modeled with open-ended questions, closed-ended questions, and listening comprehension test (see Appendix 1). It attempted to uncover information in a number of areas, to determine the language backgrounds of the participants, and to find about the language use and domains of the participants (See Tables 1, 2, 3, 4, 5 \& 6)

Right after the participants completed the questionnaires, the participants were scheduled for an accent recognition test (See Table 7). The listening test was scheduled based on the participants' convenient time. A monologue of two different English accents (British and American) was selected from an English learning website: http://www.thevoicecafe.net/. The monologue was listed as the one for English learners to improve English communication in certain accents. The topic of the listening text was general, not specific to any participants' fields of study. This was to ensure that no one had the advantage over the others. The transcript of the monologue was randomly assigned to each of the readers (see Appendix 1). Later, the research participants were asked to listen to each accent twice. Each of these monologues was about twelve seconds long. After the participants listened through a loudspeaker to each accent in a classroom, they were asked to identify the accent and express their degree of likeness for each accent.

\section{Data Analysis}

Data were analyzed both quantitatively and qualitatively. The quantitative data were first categorized into personal, national, and global preference of English accent, and then statistical techniques were employed. Once the numerical data were coded, entered and checked for errors, analyses were conducted using SPSS (version 19.0). Descriptive statistics was conducted in terms of frequencies in order to calculate percentage

\section{FINDINGS AND DISCUSSIONS}

Descriptive analysis was used to determine different variables with respect to attitudinal disposition of both Filipinos and Indians towards English varieties.

Table 1 shows the experimental data on the actual domain of where Indians and Filipinos believe they first learn English. It is apparent from the table that while the majority of Indians believed to have first learnt English in school, most Filipinos claimed the language was first taught to them at home.

Table 1. Domain where English is first learnt

\begin{tabular}{ccccc}
\hline \multirow{2}{*}{ Domains } & \multicolumn{2}{c}{ Right } & \multicolumn{2}{c}{ Wrong } \\
\cline { 2 - 5 } & $\mathrm{N}$ & $\%$ & $\mathrm{~N}$ & $\%$ \\
\hline Home & 49 & 26.8 & 96 & 57.8 \\
School & 88 & 48.1 & 70 & 42.2 \\
Others & 46 & 25.1 & & \\
\hline
\end{tabular}

Table 2 compares the summary statistics for the level of awareness of PE and IE between Filipinos and Indians, respectively. From the table, it can be seen that Filipinos have a higher level of awareness regarding their own variety of English than do the Indians.

Table 2. Awareness of Local English variety

\begin{tabular}{crrrr}
\hline & \multicolumn{2}{c}{ Right } & \multicolumn{2}{c}{ Wrong } \\
\cline { 2 - 5 } & $\mathrm{N}$ & \multicolumn{1}{c}{$\%$} & $\mathrm{~N}$ & $\%$ \\
\hline Yes & 106 & 41.8 & 71 & 43.3 \\
No/I don't know & 76 & 58.2 & 93 & 56.7 \\
\hline
\end{tabular}

Table 3 provides an overview of the perceived variety of English spoken by Indians and Filipinos. From this data, it can be observed that the majority of respondents in both countries claimed to be using their own respective nativised varieties of English. However, it is clear that more Filipinos assumed to be speaking AmE than Indians. 
Table 3. Self-Assessment of Spoken Varieties

\begin{tabular}{lcccc}
\hline & \multicolumn{2}{c}{ Indian } & \multicolumn{2}{c}{ Filipinos } \\
\cline { 2 - 5 } & $\mathrm{N}$ & $\%$ & $\mathrm{~N}$ & $\%$ \\
\hline Own variety & 57 & 37.0 & 47 & 31.9 \\
British English & 38 & 24.7 & 31 & 21.1 \\
American English & 27 & 17.5 & 42 & 28.6 \\
I do not know & 32 & 20.8 & 27 & 18.4 \\
\hline
\end{tabular}

As far as the variety of English preference for personal communication is concerned, it appears in Table 4 that respondents from both countries prefer and aspire to speak BrE. However, while Indians gave a second preference to their standard local variety of English, most Filipinos ranked AmE as their second choice of aspired variety of English.

Table 4. Preferred Model of English for Personal Communication

\begin{tabular}{lcccc}
\hline & \multicolumn{2}{c}{ Indian } & \multicolumn{2}{c}{ Filipinos } \\
\cline { 2 - 5 } & $\mathrm{N}$ & $\%$ & $\mathrm{~N}$ & $\%$ \\
\hline Own variety & 41 & 26.6 & 46 & 28.1 \\
British English & 31 & 33.8 & 52 & 40.2 \\
American English & 52 & 20.1 & 66 & 31.7 \\
I do not know & 30 & 19.5 & - & - \\
\hline
\end{tabular}

From the data in Table 5, it is clear that unlike Indians who prefer their local standard variety, Filipinos prefer foreign variety of English, especially American English, to express their national identity in ELF communication.

Table 5. Preferred Model of English for National Communication

\begin{tabular}{lcccc}
\hline & \multicolumn{2}{c}{ Indian } & \multicolumn{2}{c}{ Filipinos } \\
\cline { 2 - 5 } & $\mathrm{N}$ & $\%$ & $\mathrm{~N}$ & $\%$ \\
\hline Own variety & 53 & 33.5 & 46 & 30.9 \\
British English & 28 & 17.7 & 47 & 19.5 \\
American English & 33 & 20.9 & 29 & 31.5 \\
I do not know & 44 & 27.8 & 27 & 18.1 \\
\hline
\end{tabular}

Data in Table 6 shows that Indians and Filipinos prefer $\mathrm{BrE}$ and $\mathrm{AmE}$, respectively, to express their global identities in ELF communication.

Table 6. Preferred Model of English for Global Communication

\begin{tabular}{lcccc}
\hline & \multicolumn{2}{c}{ Indian } & \multicolumn{2}{c}{ Filipinos } \\
\cline { 2 - 5 } & $\mathrm{N}$ & $\%$ & $\mathrm{~N}$ & $\%$ \\
\hline Own variety & 52 & 19.3 & 32 & 21.3 \\
British English & 34 & 29.5 & 33 & 22.0 \\
American English & 38 & 21.6 & 57 & 38.0 \\
I do not know & 52 & 29.5 & 28 & 18.7 \\
\hline
\end{tabular}

Table 7 compares the percentage of participants who were able to distinguish between $\mathrm{AmE}$ and BrE. What is interesting in this data is that an ample number of Filipino respondents who performed better in this task than their Indian counterparts.

Respondents were asked to describe their nativised variety of English. Both Filipinos and
Indians shared a common view in their responses. However, Indian respondents were able to give a more comprehensive definition of their own variety of English than their Filipinos counterparts. Some interviewees described it as a mixture of English and their respective mother tongue, while others considered it as an inferior English variety compared to the standard variety. Moreover, some informants felt that the local variety differed from standard variety only at phonological level, while others opined that the differences only occurred at lexical and syntactical levels.

Table 7. Accent Recognition

\begin{tabular}{lrccc}
\hline & \multicolumn{2}{c}{ Right } & \multicolumn{2}{c}{ Wrong } \\
\cline { 2 - 5 } & \multicolumn{1}{c}{$\mathrm{N}$} & $\%$ & $\mathrm{~N}$ & $\%$ \\
\hline Indians (146) & 77 & 52.7 & 69 & 47.3 \\
Filipinos (148) & 141 & 89.0 & 17 & 11.0 \\
\hline
\end{tabular}

In reviewing the literature, no empirical data were found on the domain (functional nativeness) where English is first learnt in both the Philippines and India. This part of investigation is critical because it can be used as an indicator to determine the function of language in every domain, that is the functional nativeness, which is the degree of rootedness of a language in different locales (Kachru, 2005). The current study found that school as an institution is the domain where English is first learnt in India (48.1\%), while Filipinos claimed that they were first introduced to English at home $(57.8 \%)$. The result may be explained by the fact that L1 has a higher status than does English in India. That also demonstrates the reason why English language learning does not begin until grade five in the country's educational system (Agarwal, 1993). On the other hand, the high English proficiency among Filipinos is attributed to the usage of English at home (Vizconde, 2006). The author stated that most parents teach and communicate with their children in English at home.

The present study was also designed to examine the level of awareness of standard local variety and its description. The result of this study showed that people's perception of their respective varieties varies from one individual to another. Some of the definitions and descriptions, such as mother tongue's influence on English which consequently forms the standard local variety of English, must obviously express cultural norms matching those observed in past studies.

Considering that all the informants of this study were highly educated and the level of awareness of PE among Filipinos (43.3\%) was higher compared to their Indian counterparts (41.8\%), then it can be argued that the earlier assumptions by Pefianco Martin (2014) that the degree of English local variety awareness corresponds to individual level of education may not be valid. It is still difficult to explain this result, but 
it might be due to the possibility of an educated individual not giving a deep serious thought to the nature of English s/he speaks.

Regarding the variety of English between the two groups of informants, the study revealed that the majority of both groups admitted to be speaking their standard local English variety. Even though few Filipinos claimed to be speaking AmE (31.7\%), the finding is not disappointing, for both groups belong to the outer circle where English was not originally spoken. Nevertheless, the language has been influenced by local language varieties and cultures. It is apparent that the people will be communicating in their respective nativised varieties of English.

On the preference of a variety of English to express personal identity for ELF communication and the reasons for such choices by the informants, the most interesting finding was that both Filipinos and Indians wish to speak BrE. Several reasons were given to learn $\mathrm{BrE}$, AmE, and IE, but it seems the motive to learn BrE influences their idealized linguistic norm at personal level. One unanticipated finding is that few Filipino respondents (31.7\%) would prefer AmE being the variety introduced to them by the Americans who were once their colonizer, while few Indians (26.6\%) would consider their own local variety as a second preference to express their personal identity. Overall, this current study has failed to support previous research, which cited colonial history as a factor that influences an ideal English variety for personal communication (Shaw, 1981). Thus, it can be noted that $\mathrm{BrE}$ is chosen for its universal acceptance or standard grammar and pronunciation.

Another question this study sought to examine is the preferred English model to express national identity in ELF communication. This experiment revealed that Indians (33.5\%) preferred their own local variety for national communication. On the other hand, Filipinos chose foreign English varieties, especially $\mathrm{AmE}$ (31.5\%) rather than $\mathrm{PE}$ $(30.9 \%)$. Considering the effect of solidarity in making choice at this level of communication (Lewko, 2012), one would have expected the majority of Filipinos to prefer their own model of English like their Indian counterparts. Therefore, based on the three developmental stages of English varieties propounded by Kachru (1992), it can thus be argued that the Indian variety is at the full stage of development (third phase) due to its recognition as the norm and its social acceptance. However, Filipino English is still at its second phase of developmental process because an equal majority of the Filipinos still support and promote the existence of the local and imported varieties, thereby causing the varieties to exist side by side. In other words, an equal number of Filipinos promote both PE and foreign English varieties simultaneously.
This study was also set out to investigate the preferred English model for global communication. It is interesting to note that while Indians $(29.5 \%)$ favored BrE, Filipinos (38\%) prefered AmE to express global culture in ELF communication. It is clear that the choice of both nationalities is highly influenced by their respective colonial history. These findings suggest that the impact of colonial history on the choice of model English is significant for global communication. In other words, the preferred model for English communication at global level is seen through the eyes of the former colonizer.

The final objective of this study was to determine the level of awareness of native English varieties by testing the ability of both nationals in identifying the difference between AmE and BrE. It was revealed that Filipinos (89\%) performed better in the task than the Indian respondents $(52.7 \%)$. Several factors such as high familiarity and better exposure among the Filipinos to the native English variety must have been responsible for this feat. Therefore, this result explains the reason behind the high national acceptability and awareness of IE at the detriment of the knowledge of foreign native English accent among Indians.

\section{CONCLUSION}

This study set out to determine the preferred model of English to express personal, national, and global identities in ELF communication among Filipinos and Indians. The overall findings showed that both groups prefer British English for their personal communication. But for national communication, Indians preferred their own standard variety, whereas the majority of Filipinos chose a native variety of English, especially American English. The most ideal variety of English for international communication is BrE for Indians, while AmE is highly preferred at this level by Filipinos. The following major conclusions can be drawn from this present study. First, British English is globally accepted for personal communication. In addition, Indians tend to show more solidarity to their own variety of English than do Filipinos. Finally, colonial history influences both nationals in preference to their respective institutionalized variety of English for global communication. This is the first study reporting idealized linguistic norm for personal, national, and global communication between two different nationals in the outer circle who shared different colonial histories. The major limitation of this study is the adoption of descriptive statistics rather than inferential one which can help us to observe significant differences between the variables of both groups. Further work is not only needed to establish significant differences in the preferences of English models between these two nationalities but also determine the perception of 
each other's varieties and the ones within the inner circle.

\section{REFERENCES}

Agarwal, S. P. (1993). Commissions and Committees in India. New Delhi: Concept Publishing Company.

Alftberg, A. K. (2009). British or American English?: Attitudes, awareness and usage among pupils in a secondary school (Unpublished bachelor's thesis). University of Gävle, Sweden.

Arnett, J. J. (2002). The psychology of globalization. American psychologist, 57(10), 774-783.

Ball, P. (1983). Stereotypes of anglo-saxon and nonanglo-saxon accents: Some exploratory Australian studies with the matched guise technique. Language Sciences, 5(2), 163-183. https://doi.org/10.1016/S0388-0001(83)800217.

Bautista, M. L. (2000). Defining standard Philippine English: Its status and grammatical features. Manila: De La Salle University Press.

Bonvillain, N. (2003). Language, culture, and communication: The meaning of messages. Upper Sattle River, New Jersey: Prentice Hall.

Castro, M. C. A., \& Roh, T. R. D. G. (2013). The effect of language attitudes on learner preferences: A study on South Koreans' perceptions of the Philippine English accent. ELTWorldOnline.com, 5, 1-22. Retrieved from blog.nus.edu.sg

Chan, K. L. R. (2016). Hong Kong English: Will the English teachers' attitudes and their perceptions on segmental features of HKE affect their teaching practices? Proceedings of CLaSIC, 42-55.

Chye, D. Y. S. (2010). Standard English and Singlish: The clash of language values in contemporary Singapore'. In Y. Treis \& R. de Busser (Eds.), Selected Papers from the 2009 Conference of the Australian Linguistic (1-33). Retrieved from http://www.als.asn.au.

Constantino, R. (1975). The Philippines: A past revisited. New York: Monthly Review Press.

Crystal, D. (1999). The future of Englishes. English Today, 15(2), 10-20.

Dörnyei, Z. (2005). The psychology of the language learner: Individual differences in second language acquisition. Mahwah, NJ: Lawrence Erlbaum Associates.

Ferguson, C. A. (1996). English in South Asia: Imperialist legacy and regional asset. In Robert J. Baumgardner (Ed.) South Asian English: Structure, use, and users (pp. 29-39). Urbana: University of Illinois Press.

Gimson, A. C. (1981). An introduction to the pronunciation of English ( $3^{\text {rd }} \mathrm{ed}$.). London:
Edward Arnold.

Gonzalez, A. (1982). English in the Philippine mass media. In John B. Pride (Ed.) New Englishes (pp. 211-226). Rowley, Massachusetts: Newbury House Publishers, Inc.

Görlach, M. (1988). Varieties of English worldwide: Where we stand. Links \& Letters, 5, 1336.

Gu, M. (2010). National identity in EFL learning: A longitudinal inquiry. Changing English-Studies in Culture and Education, 17(1), 57-67.

Hohenthal, A. (2003). English in India: Loyalty and attitudes. Language in India, 3, 1-107.

Jaber, M., \& Hussein, R. (2011). Native speakers' perception of non-native English speech. English Language Teaching, 4(4), 77-87.

Jenkins, J. (2003). World Englishes: A resource book for students. Brighton: Psychology Press.

Kachru, B. B. (1983). The Indianization of English: The English language in India. New Delhi: Oxford University Press.

Kachru, B. B. (1985). Standards, codification and sociolinguistic realism: The English language in the outer circle. In R. Quirk and H.G. Widdowson (Eds), English in the world: Teaching and learning the language and literatures (pp. 11-30). Cambridge: Cambridge University Press.

Kachru, B. B. (1992). Teaching world Englishes. In B. B. Kachru (Ed.), The other tongue: English across cultures (pp. 355-365). Urbana, IL: University of Illinois Press.

Kachru, B. B. (2005). Asian Englishes: Beyond the canon. Retrieved from http://www.scopus.com/inward/record.url?eid= 2-s2.0-84897303988\&partnerID=tZOtx3y1

Kirkpatrick, A. (2007). World Englishes paperback with audio CD: Implications for international communication and english language teaching. Cambridge: Cambridge University Press.

Labov, W. (1966). The social stratification of English in New York City. Washington, D.C.: Center for Applied Linguistics.

Lamb, M. (2004). Integrative motivation in a globalizing world. System, 32, 3-19. doi:10.1016/j.system.2003.04.002.

Liamzon, T. A. (1969). Standard Filipino English. Manila: Ateneo University Press.

Lewko, A. M. (2012). Linguistic projection and the ownership of English: Solidarity and power with the English language in Egypt (Doctoral dissertation). The American University in Cairo, Egypt.

Lintunen, P. (2002). Gimson's Pronunciation of English (review). Language, 78(4), 821-821. https://doi.org/10.1353/lan.2003.0046

Malicsi, J. (2010). Philippine English: A case of language drift. Ritsumeikan Language and Culture Study, 22(1), 29-58.

Mardijono, J. J. (2005). English accent evaluation: 
A study on Indonesian EFL learners' perception. $K @ t a, 5(2), 147-164$.

McArthur, T. (2003). English as an Asian language. English Today, 19(2), 89-108. https://doi.org/10.1017/S0266078403002049.

McGuire, W. J. (1986). The vicissitudes of attitudes and similar representational constructs in twentieth century psychology. European Journal of Social Psychology, 16(2), 89-130. http://dx.doi.org/10.1002/ejsp.

Nesdale, A. R., \& Rooney, R. (1990). Effect of children's ethnic accents on adults' evaluations and stereotyping. Australian Journal of Psychology, 42, 309-319.

Pefianco Martin, I. (2014). Philippine English revisited. World Englishes, 33(1), 50-59. DOI: 10.1111/weng.12054

Pennycook, A. (2006). Global Englishes and transcultural flows. New York: Routledge.

Seidlhofer, B. (2006). English as a lingua franca in the expanding circle: What it isn't. In R. Rubdy \& M. Saraceni (Eds.), English in the World: Global Rules, Global Roles (pp. 40-50). London: Continuum.

Shaw, W. D. (1981). Asian student attitudes towards English. In L. Smith (Ed.) English for crosscultural communication (pp. 108-122). London: Macmillan.

Smith, L. E. (1978): Some distinctive features of EIIL vs. ESOL in English language education.
In L. Smith (Ed.), English for cross-cultural communication (pp. 13-21). London: Macmillan.

Söderlund, M., \& Modiano, M. (2002). Swedish upper secondary school students and their attitudes towards AmE, BrE and Mid-Atlantic English. In M. Modiano (Eds.), Studies in MidAtlantic English (pp. 141-171). Gävle: Högskolan i Gävle.

Sung, C. C. M. (2016). ESL university students' perceptions of their global identities in English as a lingua franca communication: A case study at an international university in Hong Kong. Asia-Pacific Education Researcher, 25(2), 305-314.

Tan, Y. Y., \& Castelli, C. (2013). Intelligibility and attitudes: How American English and Singapore English are perceived around the world. English World-Wide, 34(2), 177-201.

Thompson, R. M. (2003). Filipino English and Taglish: Language switching from multiple perspectives. Philadelphia; Amsterdam: John Benjamins Publishing. doi:10.1075/veaw.g31

Tsui, A., \& Bunton, D. (2000). The discourse and attitudes of English language teachers in Hong Kong. World Englishes, 19(3), 287-303.

Vizconde, C. (2006). Attitudes of student teachers towards the use of English as language of instruction for science and mathematics. Philippines Linguistics Journal, 1(3), 7-33. 


\section{Appendix 1 \\ Questionnaire}

\section{Personal details}

Male $\square$ Female $\square$

Where did you first begin learning English? (Please select one answer only) at home $\square$ at school $\square$ in your locality $\square$ others $\square$..........

\section{Varieties of English}

A. Have you heard of the variety of English called Indian English? (Please select one answer only) Yes

$$
\text { No }
$$
Don't know

$\mathrm{A}_{2 .}$. If you answered yes, please give a definition for this term?

B. Which variety of English do you think you speak? (Please select one answer only)
A Indian English
B British English
American English
Don't know

Others

C. Which variety of English do you aspire to speak? (Please select one answer only)
A Indian English
B British English
American English
Don't know
Others
$\mathrm{C}_{2}$ Please give reasons for this choice?
D. What variety of English do you think should be spoken generally in India? (Please select one answer only)
British English $\square$ American English $\square$ Philippine English $\square$ Others $\square . .$.

Don't know/ don't mind $\square$

E. Which variety of English do you think should be used for global communication? (Please select one answer only)

British English $\square$ American English $\quad$ Philippine English $\square$ Others $\square . .$.

Don't know/ don't mind $\square$

\section{Accent Recognition Survey}

1. Can you identify foreign English accents? Yes/No

2. Identify British and American accent from these two recordings

a. Recording 1 is

b. Recording 2 is

3. Based on these two recordings, which of these two accents do you like more?

\section{Transcript}

"Oh there you are. I was starting to wonder what had happened to you. Luckily I had a book on me to pass the time. Anyway, even if we do get there a bit late, no one's going to mind much, are they?" 